\title{
Perbedaan Kekuatan Transversa Resin Akrilik Heat Cured yang Direndam pada Larutan Eeffervescent dan Perasan Daun Salam (Eugenia Polyantha Wight)
}

\author{
Chintya Citra K ${ }^{1}$, Evelyna A ${ }^{1}$, Sutanto D \\ Fakultas Kedokteran Gigi, Universitas Kristen Maranatha, Bandung 40164, Indonesia \\ E-mail: chintyacitra353@yahoo.com
}

\begin{abstract}
Abstrak
Saat ini pembersih yang sering digunakan untuk membersihkan gigi tiruan sebagian lepasan adalah larutan effervescent dibantu dengan metode mekanik yaitu menyikat gigi tiruan menggunakan sikat gigi berbulu halus dan pasta gigi. Masalah dari metode pembersihan tersebut adalah dapat menurunkan kekuatan landasan gigi tiruannya. Penelitian ini bertujuan untuk mengetahui pengaruh perasan daun salam sebagai pembersih gigi tiruan terhadap kekuatan transversa resin akrilik heat cured. Spesimen akrilik berukuran $65 \times 13 \times 3.3 \mathrm{~mm}$ sebanyak 24 buah direndam dalam larutan effervescent dan perasan daun salam dengan variasi waktu yang berbeda 30 menit dan 8 jam selama 7 hari, lalu diuji kekuatan transversanya dengan Universal Testing Machine. Didapatkan perbedaan kekuatan transversa resin akrilik heat cured yang direndam larutan effervescent dan perasan daun salam, kelompok perasan daun salam 8 jam mengalami peningkatan kekuatan transversa secara signifikan sebesar $-83.5 \mathrm{~N}$ lebih tinggi dibanding kelompok larutan effervescent 8 jam. Kandungan fenol $\leq 0.005 \%$ daun salam tidak menyebabkan difusi berlebihan pada resin akrilik. Kesimpulannya terdapat perbedaan kekuatan transversa resin akrilik heat cured yang direndam pada larutan effervescent dan perasan daun salam.
\end{abstract}

Kata kunci : daun salam; effervescent; kekuatan transversa; pembersih gigi tiruan.

\section{THE DIFFERENCE OF TRANSVERSA STRENGTH OF RESIN ACRYLIC HEAT CURED THAT SOAKED IN EFFERVESCENT AND SQUEEZED BAY LEAF (Eugenia Polyantha Wight)}

\begin{abstract}
Currently the most commonly used cleanser for cleaning removable partial dentures is the effervescent solution assisted by the mechanical method of brushing the denture with a fluffy toothbrush and toothpaste. The problem of the cleaning method is potentially lowering the denture base strength. This research is to know whether the bay leaves leaf as denture cleanser can influence the transverse strength of heat cured acrylic resin. Acrylic specimens measuring $65 \times 13 \times 3.3 \mathrm{~mm}$ of 24 pieces were soaked into effervescent solution and squeezed bay leaves with different time variations of 30 minutes and 8 hours for 7 days. After that, the transverse power test using Universal Testing Machine. From the results obtained the difference of transverse power of heat cured acrylic resin soaked effervescent solution and squeeze of bay leaf, where the group of leaves of bay leaf 8 hours has increased transversa strength significantly equal to $-83.5 \mathrm{~N}$ that is higher than group of 8 hours effervescent solution. The phenol $\leq$
\end{abstract}


$0.005 \%$ in bay leaves does not cause excessive diffusion of acrylic resins. In conclusion there is a difference in the transverse strength of a heat-cured acrylic resin soaked in effervescent solution and a squeeze of bay leaf.

Key words bay leave; denture cleanser; effervescent; transversal strength.

\section{Pendahuluan}

Kehilangan gigi merupakan salah satu perubahan jaringan rongga mulut. Gigi hilang yang tidak segera diganti dapat menimbulkan gangguan bagi pasien seperti pada sistem mastikasi, fonetik, estetik, maloklusi, gangguan TMJ dan gangguan psikologis. Riset Kesehatan Dasar (RISKESDAS) menyatakan di Indonesia kasus kehilangan gigi didominasi oleh kelompok masyarakat usia 45 tahun ke atas, yaitu sebesar 14,5\%. Penanganan kehilangan gigi dilakukan dengan pembuatan gigi tiruan. ${ }^{1-3}$

Gigi tiruan sebagian lepasan menurut Glossary of Prosthodontic adalah gigi tiruan yang menggantikan satu atau beberapa gigi yang hilang dengan gigi tiruan dan didukung oleh gigi, mukosa atau kombinasi gigi dengan mukosa yang dapat dilepas dan dipasangkan kembali oleh pasien. Gigi tiruan sebagian lepasan dibuat dengan tujuan memperbaiki estetik, mastikasi, fonetik, oklusi, meningkatkan distribusi beban kunyah, melindungi dan mempertahankan kesehatan gigi yang masih ada serta jaringan lunak rongga mulut. Proses pembuatan dan pemeliharaan gigi tiruan sebagian lepasan praktis serta harga terjangkau, oleh karena itu GTSL sering diminati oleh pasien. ${ }^{1-2}$

Komponen gigi tiruan sebagian lepasan terdiri dari konektor mayor, konektor minor, direct retainer, indirect retainer, occlusal rest, landasan dan gigi artifisial yang melekat pada basis. Landasan merupakan salah satu komponen dari gigi tiruan sebagian lepasan yang menghubungkan bagian-bagian gigi tiruan adalah landasan. Landasan merupakan bagian penting dalam konstruksi gigi tiruan, karena menerima dan mendistribusikan gaya-gaya fungsional ke jaringan pendukung dalam rongga mulut, meningkatkan estetik, sebagai retensi dan stimulasi jaringan mukosa di residual ridge. ${ }^{4-7}$

Bahan landasan gigi tiruan yang sering digunakan adalah polimer dengan jenis resin akrilik (polimetil metakrilat). American Dental Association (ADA) membagi resin akrilik menjadi dua jenis yaitu heat cured polymer dan self cured polymer. Jenis resin akrilik yang sering digunakan yaitu heat cured polymer karena tidak toksik, tidak mengiritasi, tidak larut dalam cairan mulut, estetik, mudah dimanipulasi dan direparasi serta perubahan dimensi minimal. ${ }^{16-20}$

Pemakaian dan perawatan gigi tiruan yang tidak tepat akan menimbulkan dampak bagi pasien seperti peningkatan akumulasi plak, trauma jaringan dan penyaluran gaya kunyah. Tujuan perawatan gigi tiruan supaya kesehatan mulut pasien terjaga, mencegah pertumbuhan Candida albicans yang dapat memicu terjadinya kandidiasis, inflamasi, eritema, mencegah bau gigi tiruan (denture breath) dan berbagai penyakit mulut lainnya. Menurut spesifikasi American Dental Association (ADA) no. 33 pemeliharaan gigi tiruan dapat dilakukan dengan menyikat gigi tiruan dengan pasta gig non abrasive dan sikat gigi berbulu halus serta merendam gigi tiruan di dalam larutan pembersih gigi tiruan effervescent. Larutan pembersih gigi tiruan sering digunakan karena kemampuannya menjangkau bagian sempit dan sulit ketika hanya menggunakan sikat gigi, dapat menghilangkan plak, stain dan halitosis. Efek negatif larutan effervescent 
dapat menyebabkan kerusakan signifikan pada landasan gigi tiruan karena memiliki kandungan alkaline peroxide. Perendaman dalam jangka waktu yang berulang menunjukkan perbedaan kekuatan transversa yang signifikan pada landasan resin akrilik, perubahan warna dan kekasaran permukaan. Menurut Yuan (2012) terdapat efek yang signifikan pada kekuatan transversa pada landasan resin akrilik heat cured. $^{9,14-}$ $15,21-22$

Pembersih gigi tiruan yang ada di Indonesia berasal dari bahan impor sehingga sulit untuk didapat dan harganya mahal. Hal tersebut merupakan sebuah kendala bagi masyarakat Indonesia yang menggunakan gigi tiruan terutama bagi masyarakat yang tinggal di pedesaan, oleh karena itu banyak peneliti melakukan eksperimen menggunakan metode lain untuk membersihkan gigi tiruan, salah satunya yaitu dengan bahan-bahan tradisional. Keuntungan menggunakan bahan tradisional adalah bahan baku mudah didapat, harga terjangkau, dapat ditanam di halaman rumah sendiri dan dapat diracik sendiri. Bahan tradisional yang dapat digunakan sebagai pembersih gigi tiruan salah satunya yaitu daun salam (Eugenia polyantha Wight). Berdasarkan penelitian Dhena (2006) disimpulkan bahwa perasan daun salam dengan konsentrasi $80 \%$ yang digunakan sebagai bahan pembersih gigi tiruan efektif menurunkan jumlah Candida albicans pada landasan resin akrilik dengan waktu perendaman 20 menit. Sifat antifungi daun salam berasal dari kandungan minyak atsiri di dalamnya yang terdiri dari sitral, eugenol, tannin, flavonoid, dan fenol. Daun salam tidak hanya mempunyai efek antifungi namun juga efek antibakteri berdasarkan hasil penelitian Sumono dan Wulan (2009). $4,10-11,16,24$

\section{Metode Penelitian}

Penelitian ini merupakan penelitian eksperimental laboratorium murni dengan menggunakan enam kelompok sampel penelitian. Jumlah sampel penelitian ditentukan dengan perhitungan besar sampel untuk penelitian eksperimental dengan rumus Federer dan didapatkan hasil $r \geq 4$, dengan perhitungan tersebut diperoleh besar spesimen per kelompok adalah empat spesimen sehingga jumlah spesimen dari enam kelompok adalah 24 buah. Sampel penelitian berupa lempeng resin akrilik heat cured dengan ukuran 65 x 10 x 3,3 mm (Specification ANSI/ADA no.

12) yang direndam di dalam aquades, larutan efferevescent dan perasan daun salam dengan pengulangan selama 7 hari berturut-turut. Setiap spesimen direndam di dalam cawan petri dan masing-masing spesimen dibilas terlebih dahulu sebelum direndam kembali pada hari berikutnya.

Spesimen penelitian :

Kelompok I : Resin akrilik heat cured direndam dalam aquades selama 30 menit.

Kelompok II : Resin arilik heat cured direndam dalam larutan effervescent selama 30 menit. Kelompok III : Resin akrilik heat cured direndam dalam perasan daun salam selama 30 menit Kelompok IV : Resin akrilik heat cured direndam dalam aquades selama 8 jam.

Kelompok V : Resin akrilik heat cured direndam dalam larutan effervescent selama 8 jam. Kelompok VI : Resin akrilik heat cured direndam dalam perasan daun salam selama 8 jam. 

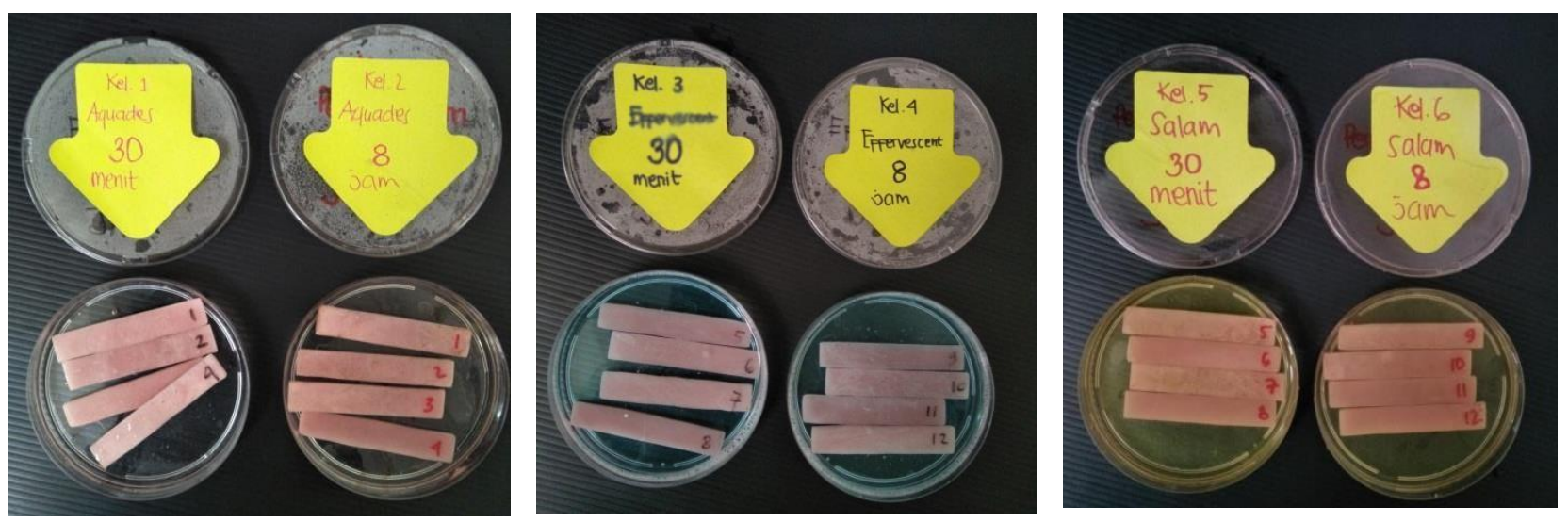

Figure 1. Perendaman Resin Akrilik Heat Cured pada Larutan Aquades,

\section{Larutan Effervescent dan pada Perasan Daun Salam}

Setelah spesimen diberi perlakuan, maka dilakukan pengujian kekuatan transversa dengan metode three point bending menggunakan Universal Testing Machine Shmadzu Autograph AGS-X Series $50 \mathrm{kN}$, Japan. Bagian tengah spesimen diberi tanda dengan menggunakan pensil, setelah itu spesimen diletakan pada lower span dan posisi bagian tengah spesimen yang sudah ditandai tepat di bawah upper bending jig. Ketika alat uji dinyalakan, hidrolik akan turun dan upper bending jig akan menekan bagian tengah spesimen yang bertumpu pada kedua ujung kanan dan kiri sampai spesimen uji patah dan alat uji akan berhenti bekerja secara otomatis. Load cell yang digunakan sebesar $5 \mathrm{kN}$ dengan kecepatan 50,036 $\mathrm{mm} / \mathrm{min}$.

Penelitian ini menggunakan analisis statistik ANOVA one way dilanjutkan dengan metode Tukey HSD bila terdapat perbedaan.

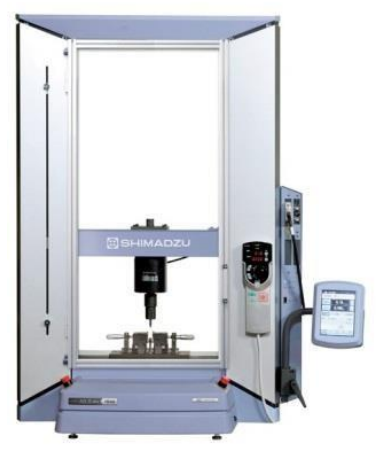

Figure 2. Shimadzu AGS-5kNx. ${ }^{43}$

\section{Hasil}

Hasil penelitian yang diperoleh diuraikan pada tabel dan diagram di bawah ini : 
Tabel 1. Data Kekuatan Tranversa Resin Akrilik Heat Cured

\begin{tabular}{|c|c|c|c|c|c|c|}
\hline Kelompok & $\begin{array}{l}\text { Aquades } 30 \\
\text { menit }(\mathrm{N})\end{array}$ & $\begin{array}{l}\text { Effervescent } 30 \\
\text { menit }(\mathrm{N})\end{array}$ & $\begin{array}{c}\text { Perasan } \\
\text { daun salam } 30 \\
\text { menit } \\
\text { (N) }\end{array}$ & $\begin{array}{l}\text { Aquades } \\
8 \text { jam }(\mathrm{N})\end{array}$ & $\begin{array}{l}\text { Effervescent } 8 \\
\operatorname{jam}(\mathrm{N})\end{array}$ & $\begin{array}{r}\text { Perasan } \\
\text { daun salam } \\
8 \text { jam }(N)\end{array}$ \\
\hline 1 & 94.29 & 110.71 & 189.60 & 160.88 & 130.80 & 147.55 \\
\hline 2 & 83.65 & 115.01 & 158.69 & 125.24 & 147.31 & 167.38 \\
\hline 3 & 90.36 & 101.35 & 177.62 & 143.51 & 151.52 & 177.87 \\
\hline 4 & 83.36 & 120.61 & 159.75 & 157.93 & 198.01 & 273.36 \\
\hline Rerata & 87.91 & 111.92 & 171.41 & 146.89 & 156.91 & 191.54 \\
\hline
\end{tabular}

Diagram 1. Rerata Kekuatan Transversa Resin Akrilik Heat Cured

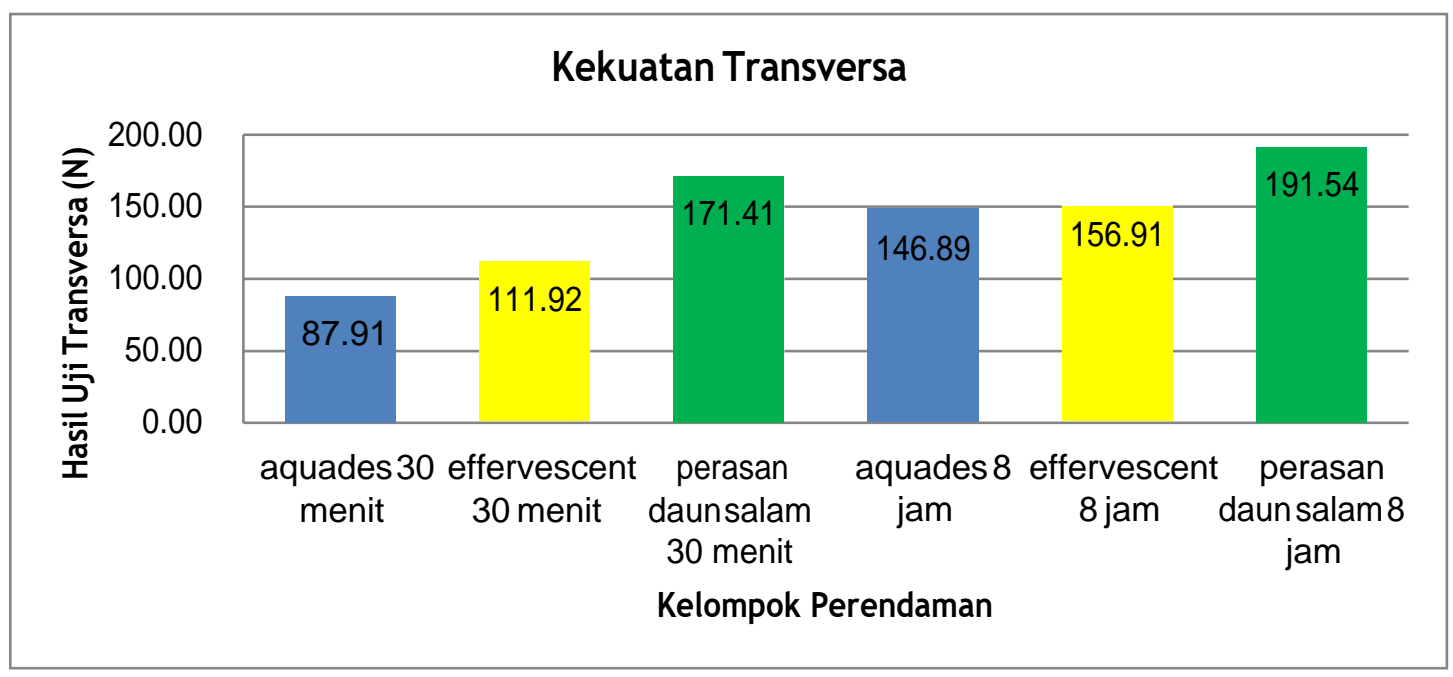

Berdasarkan tabel 1 dan diagram 1 kelompok yang memiliki rerata kekuatan transversa paling tinggi adalah kelompok spesimen yang direndam selama 8 jam dengan perasan daun salam sebesar $191.54 \mathrm{~N}$ dan kelompok yang memiliki rerata terendah adalah kelompok kontrol yang direndam dengan aquades selama 30 menit sebesar 87.91 $\mathrm{N}$.

Sebelum dilakukan analisis dengan metode One-Way ANOVA, dilakukan uji normalitas berdasarkan dari data kekuatan transversa resin akrilik heat cured dengan menggunakan uji Shapiro Wilk. Berdasarkan hasil uji normalitas diperoleh hasil $\mathrm{p} \geq 0.05$ sehingga dapat disimpulkan bahwa seluruh data berdistribusi normal. Selanjutnya dilakukan uji homogenitas menggunakan uji Levene dan didapatkan hasil p=0.024 dimana data dinyatakan homogeny karena $\mathrm{p}>0.05$. Kemudian dilakukan analisis statistik dengan One-Way ANOVA untuk mengetahui pengaruh perendaman spesimen akrilik. Hasil analisis statistik diuraikan pada tabel berikut : 
Tabel 2. Hasil Uji Statistik One-Way ANOVA

\begin{tabular}{lcccc}
\hline Kelompok & $\mathrm{n}$ & Rerata \pm SD & $\mathrm{F}$ & $\mathrm{p}$ \\
\hline Aquades 30 menit & 4 & $87.91 \pm 5.34$ & & \\
Effervescent 30 menit & 4 & $111.91 \pm 8.13$ & \\
$\begin{array}{l}\text { Perasan daun salam } \\
\text { menit } \\
\text { Aquades 8 jam }\end{array}$ & 30 & 4 & $171.41 \pm 14.91$ & \\
$\quad$ Effervescent 8 jam & 4 & $146.88 \pm 16.31$ & \\
Perasan daun salam 8 jam & 4 & $156.90 \pm 28.82$ & \\
\end{tabular}

Nilai $\mathrm{p}=0.000$ sehingga dapat disimpulkan terdapat perbedaan yang signifikan antara kekuatan transversa resin akrilik heat cured yang direndam pada larutan effervescent dan pada larutan perasan daun salam. Selanjutnya dilakukan uji lanjutan dengan uji Tukey untuk mengetahui kelompok yang memiliki kekuatan transversa yang bermakna. Analisis statistik dengan uji Tukey diuraikan pada tabel berikut :

Tabel 3. Uji Tukey Rerata Kekuatan Transversa Resin Akrilik Heat Cured dengan Perendaman selama 30 menit dan 8 jam

\begin{tabular}{|c|c|c|c|c|c|c|}
\hline \multirow[t]{2}{*}{ Kelompok } & \multicolumn{5}{|c|}{ Perasan } & $\begin{array}{c}\text { Perasan } \\
\text { aun salam } 8\end{array}$ \\
\hline & 30 menit & 30 menit & menit & 8 jam & 8 jam & \\
\hline Aquades 30 menit & & -24 & $-83.5^{*}$ & -58.9 & $-68.9 *$ & $-103.6^{*}$ \\
\hline $\begin{array}{l}\text { Effervescent } 30 \\
\text { menit }\end{array}$ & 24 & & -59.4 & -34.9 & -44.9 & $-79.6^{*}$ \\
\hline $\begin{array}{l}\text { Perasan daun salam } \\
30 \text { menit }\end{array}$ & $83.5^{*}$ & 59.4 & & 24.5 & 14.5 & -20 \\
\hline Aquades 8 jam & 58.9 & 34.9 & -24.5 & & -10 & -44.6 \\
\hline Effervescent 8 jam & $68.9 *$ & 44.9 & -14.5 & 10 & & -34.6 \\
\hline $\begin{array}{l}\text { Perasan daun salam } \\
8 \text { jam }\end{array}$ & 103.6* & $79.6^{*}$ & 20 & 44.6 & 34.6 & \\
\hline
\end{tabular}

Pada tabel 3 menunujukan hasil peningkatan kekuatan transversa resin akrilik heat cured secara signifikan pada kelompok perendaman aquades selama 30 menit terhadap 
kelompok perendaman perasan daun salam selama 30 menit sebesar -83.5 dengan signifikansi $p=0.005$, hasil penurunan kekuatan transversa resin akrilik heat cured secara signifikan pada kelompok perendaman perasan daun salam selama 30 menit terhadap kelompok perendaman aquades selama 30 menit sebesar 83.5 dengan signifikansi $p=0.005$.

\section{Diskusi}

Hasil penelitian ini bertujuan untuk mengetahui perbedaan kekuatan transversa antara resin akrilik heat cured yang direndam pada larutan effervescent dan yang direndam pada perasan daun salam. Tabel 1 menunjukan rerata kekuatan transversa resin akrilik heat cured setelah diberikan perlakuan, rerata kekuatan transversa yang paling besar dimiliki oleh kelompok resin akrilik heat cured yang direndam dalam perasan daun salam selama 8 jam sebesar $191.54 \mathrm{~N}$ sedangkan rerata kekuatan transversa yang paling rendah dimiliki oleh kelompok resin akrilik heat cured yang direndam dalam aquades selama 30 menit sebagai kelompok kontrol sebesar 87.91 N. Rerata kekuatan transversa resin akrilik heat cured pada kelompok perendaman aquades selama 30 menit, larutan effervescent selama 30 menit, aquades selama 8 jam dan larutan effervescent selama 8 jam lebih rendah jika dibandingkan dengan kelompok perendaman dengan perasan daun salam selama 8 jam. Hal ini menunjukan bahwa kelompok perendaman perasan daun salam selama 30 menit dan selama 8 jam dapat meningkatan kekuatan transversa resin akrilik heat cured jauh lebih baik dibandingkan dengan kelompok lainnya.

Berdasarkan tabel 2 terdapat perbedaan kekuatan transversa yang signifikan antara resin akrilik heat cured yang direndam pada larutan effervescent dan yang direndam dalam perasan daun salam, oleh karena itu akan dilakukan uji Tukey untuk melihat rerata hasil kekuatan transversa pada 6 kelompok resin akrilik heat cured yang direndam pada larutan effervescent dan yang direndam pada perasan daun salam. Dari hasil rerata tabel 3 yang mengalami peningkatan kekuatan transversa secara signifikan adalah kelompok perendaman pada perasan daun salam selama 8 jam sebesar -103.6, kelompok perendaman pada perasan daun salam selama 30 menit sebesar -83.5 dan kelompok perendaman dengan larutan effervescent selama 8 jam sebesar -68.9. Kelompok resin akrilik heat cured yang direndam pada perasan daun salam dengan variasi waktu yang berbeda yaitu 30 menit dan 8 jam selalu menunjukan peningkatan pada kekuatan transversanya jika dibandingkan dengan kelompok resin akrilik heat cured yang direndam pada larutan effervescent dan yang direndam pada aquades sebagai kelompok kontrol. Hal ini dapat disebabkan oleh kandungan fenol $0.05 \%$ pada perasan daun salam dapat mempengaruhi peningkatan kekuatan transversa resin akrilik heat cured, sedangkan kandungan sulfamic acid yang terdapat pada larutan effervescent dapat mempengaruhi penurunan kekuatan transversa resin akrilik heat cured dan cairan aquades tidak dapat meningkatkan kekuatan transversa resin akrilik heat cured karena tidak memiliki zat atau senyawa yang dapat mempengaruhi peningkatan kekuatan transversanya. 15

Kehilangan gigi dapat terjadi karena beberapa faktor yang mempengaruhi seperti karies, kerusakan jaringan periodontal dan trauma. Gigi tiruan merupakan salah satu solusi untuk menangani masalah kehilangan gigi, dimana gigi tiruan akan menggantikan satu atau beberapa gigi yang hilang dengan dukungan gigi asli, mukosa atau kombinasi keduanya. Pembuatan gigi tiruan diperlukan untuk menghindari efek jangka panjang yang merugikan akibat dari kehilangan gigi. Terdapat beberapa macam gigi tiruan dan 
salah satunya adalah gigi tiruan lepasan, gigi tiruan sebagian lepasan masih banyak diminati karena merupakan metode yang praktis dan ekonomis untuk menggantikan satu atau lebih kehilangan gigi. 3,18-19

Gigi tiruan sebagian lepasan pada umumnya menggunakan resin akrilik heat cured sebagai bahan landasan. Resin akrilik heat cured memiliki sifat fisik dan mekanik dan kedua sifat ini memiliki peranan penting dalam ketahan resin akrilik heat cured sebagai bahan landasan gigi tiruan yang sering digunakan. Kekuatan transversa merupakan salah satu sifat fisik dari resin akrilik heat cured dan merupakan syarat landasan gigi tiruan. Kekuatan transversa landasan gigi tiruan merupakan salah satu hal yang penting untuk diketahui terutama pada saat mastikasi karena akan terjadi peregangan landasan selama proses mastikasi dan hal tersebut dapat menyebabkan crazing. Uji kekuatan transversa dapat memberikan gambaran mengenai ketahanan suatu benda dalam menerima beban pada saat mastikasi. Pemilihan bahan pembersih gigi tiruan juga memiliki peranan besar dalam mempengaruhi kekuatan transversa landasan gigi tiruan, karena pembersih gigi tiruan akan digunakan setiap hari dan dalam jangka waktu yang panjang. Pembersih gigi tiruan yang mengandung zat atau senyawa tertentu dapat memberikan dampak yang baik ataupun buruk terhadap kekuatan transversa landasan gigi tiruan, oleh karena itu pemilihan bahan pembersih gigi tiruan yang tepat sangat diperlukan. Beberapa hal yang juga dapat mempengaruhi kekuatan transversa suatu landasan gigi tiruan salah satunya adalah tahap pembuatan landasan resin akrilik heat cured seperti teknik pengadukan monomer dan polimer resin akrilik, jarak waktu dari tahap pengisian ke dalam mould sampai pressing, jarak waktu dari proses pressing sampai proses curing dan adanya mikroporositas yang tidak terlihat. 25,45

Jenis pembersih gigi tiruan yang umum digunakan adalah gabungan antara metode mekanik dengan kimia seperti menggunakan pasta gigi non-abrasive untuk menyikat gigi tiruan menggunakan sikat gigi dengan bulu sikat yang halus, lalu dilanjutkan dengan merendam gigi tiruan di dalam larutan pembersih gigi tiruan. Kedua metode ini dapat membersihkan gigi tiruan dari stain, debris, plak, jamur dan bakteri yang dapat menyebabkan halitosis dan kelainan pada sistem stomatognaitk lainnya. Efek merugikan yang dapat timbul dari metode pembersihan gigi tiruan di atas antara lain kekuatan impak dan kekuatan tekan resin akrilik menjadi berkurang, menimbulkan goresan dan abrasi pada landasan gigi tiruan. Pada penelitian Omari (2008) perendaman resin akrilik heat cured selama 30 menit pada larutan effervescent dapat menurunkan kekuatan transversa. Harga larutan pembersih gigi tiruan juga cenderung mahal dikarenakan terbuat dari bahan impor juga merupakan kekurangan dari penggunaan larutan pembersih gigi tiruan. 4,30

Cara untuk mengatasi efek merugikan dari metode mekanik dan kimia yang ada saat ini adalah dengan metode herbal tradisional menggunakan tanaman-tanaman obat yang saat ini mulai semakin banyak dikembangkan dan diminati oleh warga Indonesia, khususnya untuk kalangan menengah ke bawah dimana bahan bakunya mudah didapat serta harga yang terjangkau dan dapat dikembangbiakan sendiri. Hal ini sesuai dengan dicanangkannya Tradisional Medicine Strategy oleh WHO pada tahun 2002. Pada penelitian ini bahan landasan gigi tiruan yang digunakan adalah resin akrilik heat cured yang akan direndam di dalam perasan daun salam, pemilihan bahan tersebut didasarkan pada ketersediaannya yang mudah untuk ditemukan di Indonesia, dari segi biaya yang lebih terjangkau dan pengolahannya sederhana tanpa memerlukan zat atau senyawa tambahan. Daun salam merupakan salah satu bahan herbal tradisional yang dapat 
digunakan, dari penelitian Dhena (2006), Geovani dan Hanindra (2012) daun salam memiliki banyak manfaat sebagai bahan pembersih gigi tiruan seperti dapat menghilangkan stain, debris, plak, jamur, bakteri serta tidak mempengaruhi penurunan kekuatan tekan dan kekuatan impak landasan gigi tiruan secara signifikan. 41-42,46

Pada penelitian ini penulis melakukan proses perendaman resin akrilik heat cured di dalam perasan daun salam, di dalam larutan effervescent dan aquades hanya sebagai kelompok kontrol. Perendaman dilakukan selama 30 menit dan 8 jam untuk melihat perbedaan kekuatan transversa resin akrilik heat cured yang sudah diberi perlakuan dan untuk melihat efektifitas perasan daun salam dalam meningkatkan kekuatan transversa. Fittydent ${ }^{\circledR}$ memberikan instruksi untuk melakukan perendaman gigi tiruan selama 30 menit di dalam larutan effervescent dan berdasarkan penelitian Dhena (2006) perendaman gigi tiruan selama 30 menit efektif dalam menurunkan jumlah Candida albicans, oleh karena itu waktu perendaman 30 menit dipilih penulis sebagai variasi waktu perendaman pertama. Pasien pada umumnya melepas dan merendam gigi tiruannya selama tidur dimalam hari $( \pm 8$ jam $)$ oleh karena itu waktu perendaman selama 8 jam ini dipilih penulis sebagai variasi waktu perendaman kedua. 46

Hasil uji kekuatan transversa menunjukan adanya peningkatan kekuatan transversa yang signifikan pada resin akrilik heat cured yang direndam dalam perasan daun salam selama 30 menit dan selama 8 jam jika dibandingkan dengan resin akrilik heat cured yang direndam dalam larutan effervescent selama 30 menit dan selama 8 jam. Peningkatan kekuatan transversa ini diakibatkan karena kandungan fenol yang terdapat pada perasan daun salam $\leq 0,05 \%$ sedangkan penurunan kekuatan transversa terjadi karena kandungan sulmafic acid dan alkaline peroxide yang terdapat dalam larutan effervescent. Fenol dapat diserap oleh permukaan resin akrilik dan menyebabkan permukaan resin akrilik mengembang dan lunak. Fenol merupakan senyawa hidrokarbon aromatik yang memiliki berat molekul lebih kecil dari pada berat molekul resin akrilik dan hal tersebut menyebabkan fenol berpenetrasi ke dalam struktur rantai resin akrilik heat cured lalu memutuskannya, oleh sebab itu terjadi peningkatan kekuatan transversa yang tidak terlalu signifikan antara kelompok perendaman dengan perasan daun salam selama 30 menit dan pada kelompok perasan daun salam selama 8 jam. Resin akrilik heat cured memiliki sifat menyerap air sebesar $0,69 \% \mathrm{mg} / \mathrm{cm}^{2}$ dan kelarutan dalam berbagai pelarut, pada penelitian ini resin akrilik menyerap berbagai zat yang terdapat di dalam perasan daun salam dan larutan effervescent selama 30 menit dan selama 8 jam dalam jangka waktu 7 hari. Resin akrilik yang direndam di dalam sebuah larutan akan terpengaruh sifat fisiknya. Larutan akan terabsorpsi ke dalam ruang mikroporositas resin akrilik dan ikatan antar molekulnya akan terpengaruhi. Semakin lama waktu perendaman maka akan semakin banyak partikel larutan yang terabsorpsi ke dalam ruang mikroporositas resin akrilik, hal ini akan membuat kekuatan mekanis akan semakin berkurang. Pengaruh dari perendaman pada larutan pembersih gigi tiruan adalah penyerapan dari cairan oleh resin akrilik heat cured sehingga polimer bereaksi sehingga resin akrilik heat cured menjadi lebih flexural. Penelitian O'Brien (2002) mengatakan bahwa resin akrilik memiliki dua macam ikatan yaitu ikatan primer dan ikatan sekunder. Ikatan primer adalah ikatan antar atom dalam rantai sedangkan ikatan sekunder merupakan ikatan antar rantai-rantainya. Ikatan primer resin akrilik memiliki kekuatan yang baik, namun ikatan sekundernya lemah dan hal ini yang menyebabkan menurunnya ketahanan resin akrilik terhadap tekanan. Ikatan sekunder yang menurun juga menyebabkan buruknya ketahanan kimiawi resin akrilik. Sifat resin akrilik yang 
mampu menyerap air memiliki efek positif dan negatif. Efek positif dari penyerapan air adalah sebagai kompensasi pengerutan atau shrinkage selama processing landasan gigi tiruan, namun di sisi lain efek negatifnya adalah terjadi degradasi akibat hidrolisis pada polimer. Ion-ion yang dibawa oleh larutan pembersih dapat menyebabkan rusaknya rantai-rantai polimer, molekul air akan menembus massa dan menempati ruang diantara rantai polimer melalui proses yang disebut difusi. Akibatnya rantai polimer akan memisah dan menimbulkan efek yang siginifikan terhadap sifat mekanis resin akrilik tersebut. 6,47

Kekuatan transversa resin akrilik yang direndam 8 jam di dalam perasan daun salam lebih tinggi daripada kekuatan transversa resin akrilik yang direndam 30 menit di dalam perasan daun salam. Hal ini menunjukan bahwa kemungkinan ruang mikroporositas resin akrilik heat cured terisi oleh residu tersisa yang terdapat pada perasan daun salam meskipun melalui tahap penyaringan pada saat pembuatan perasan tersebut. Perlu dilakukan uji lanjutan menggunakan uji SEM untuk melihat mikrostruktur permukaan resin akrilik heat cured setelah direndam di dalam perasan daun salam. Kemampuan perasan daun salam dalam meningkatkan kekuatan transversa resin akrilik heat cured juga harus diteliti dalam jangka waktu yang lebih lama karena berkaitan dengan sifat fisik resin akrilik yaitu dapat menyerap air dan kelarutan dalam berbagai pelarut.

\section{Referensi}

1. Depkes RI. Laporan Hasil Kesehatan Dasar (RISKESDAS). [serial online] 2007. Available from URL: http://www.depkes.go.id/resources/download/general/Hasil\%20Riskesdas\%202013.pdf

2 Combe EC. Notes on dental materials. $6^{\text {th }}$ ed. New York: Churchill Livingstone Inc; 1992: 282-8.

3. Rahmayani L, Herwanda, Idawani M. Perilaku Pemakai Gigi Tiruan Terhadap Pemeliharaan Kebersihan Gigi Tiruan Lepasan. Jurnal PDGI; 2013: 83-88.

4. Wulandari F. Pengaruh lama perendaman resinakrilik heat cured dalam eugenol minyak kayu manis terhadap kekuatan transversa. Journal of Prosthodontics 2012; Vol. 3 No. 1

5. Sakaguchi RL, Powers JM. Craig's Restorative Dental Materials. $13^{\text {th }}$ ed. Philadelphia: Elsevier Inc; 2012: 191.

6. Anusavice KJ. Philips: Buku Ajar Ilmu Kedokteran Gigi. Ahli bahasa: Budiman JA, Purwoko S. Jakarta: Penerbit Buku Kedokteran EGC; 2003: 197-8.

7. Richard R. Dental Materials. $2^{\text {th }}$ ed. Philadelphia: St. Louis; 2002:211-217.

8. Roberth H. Denture Cleansers. JADA Vol. 1061983 January. Available from: URL: http://www.sciencedirect.com/science/article/pii/S0002817783610248/part/firstpage-pdf

9. Kristiana D. Kekuatan transversa akrilik self cured dan akrilik heat cured direndam rebusan daun sirih sebagai bahan pembersih gigi tiruan lepasan. Majalah Ilmiah Kedokteran Gigi; 2007.

10. Sumono A, Wulan A. Kemampuan Air Rebusan Daun Salam (Eugenia Polyantha Wight) dalam Menurunkan Jumlah Koloni Bakteri Streptococcus sp. Majalah Farmasi Indonesia; 2009.

11. Dalimartha S. Atlas Tumbuhan Obat Indonesia. Jilid 1. Jakarta: Trubus Agriwidya; 1999.

12. Geovani V. Pengaruh Perasan Daun Salam (Eugenia Polyantha Wight) $80 \%$ 
sebagai Pembersih Gigi Tiruan terhadap Kekuatan Tekan Resin Akrilik Tipe Heat Cured dengan Variasi Lama Perendaman. Fakultas Kedokteran Gigi. Universitas Jember; 2012: 34-35.

13. Omari AW. Evalution of the effect of some denture cleansers on hardness of acrylic denture base and teeth materials. 2008. [Cited: 1 Agustus 2014.] Available at: http://www.iasj.net/iasj?func=fulltext\&aId=9114

14. Yuan SP, Lin H, Pan S, Lou LL, Xu YX. Effect of polident denture cleansers on the properties of heat-polymerized denture base acrylic resin. 2012. [Cited: 13 Des 2013.] Available at: http://europepmc.org/abstract/MED/23247464/reload=0;jsessionid=AC8UkTkJwLbw82uPlz $\underline{\mathrm{m} 3.60}$

15. Mese A. Bond Strength of Denture Liners Following Immersion of Denture Cleanser. Journal Biotechnology \& Biotechnological Equipment; 2006: 20: 185.

16. Sumono A, Wulan A. The Use of Bay Leaf (Eugenia Polyantha Wight) in Dentistry. Dental Journal; 2008.

17. Hanindra R. Pengaruh Perasan Daun Salam (Eugenia Polyantha Wight) 80\% sebagai Denture Cleanser terhadap Kekuatan Impak Resin Akrilik Tipe Heat Cured. Fakultas Kedokteran Gigi, Universitas Jember; 2012: 50-51.

18. Sharma A, Shashidhara. A Review Flexible Removable Partial Denture. IOSR Journal of Dental and Medical Sciences; 2014: 58-62.

19. The Academy of Prosthodontic. The Glossary of Prostodontic Term. Journal of Prosthetic Dentistry. [serial online] 2005; 31-68. Available from URL : http://www.academyofprosthodontics.org/_Library/ap_articles_download/GPT8.pdf

20. Setiawan R. Penatalaksanaan Relining pada Gigi Tiruan Sebagian Lepasan. [serial online]2003; [cited 20 Januari 2014]. Available from URL: http://ejournal.jurwidyakop3.com/index.php/jurnal-ilmiah/article/view/107

21. Philips RW. Science of dental material. 9th ed. Philadelphia: WB Saunder; 1991: 23-26, 177-213.

22. Eckert S, Jacob RF, Fenton AH, Mericske. Prosthodontic Treatment for Edentulous Patients. St. Louis: Mosby Inc; 2004: 190-205, 276-9.

23. Bahrani F, Safari A, Vojdjani M, Karampoor G. Comparison of Hardness and Surface Roughness of Two Denture bases Polymerized by Different Methods. World Journal of Dentistry; 2012: 171-175.

24. Craig RG, Powers JM, Wataha JC. Dental Material Properties and Manipulation. 8th ed. Mosby: Elsevier; 2003: 271-8.

25. Gunadi HA, Margo A, Burhan LK, Suryatenggara F, Setiabudi I. Buku Ajar Ilmu Geligi Tiruan Sebagian Lepasan. Jakarta: EGC; 1991: Jilid 1:20.

26. Wadia R. 9 Tips and Tricks for Removable Partial Dentures with Dr Manny Vasant. [Cited: 2 Jul 2016.] Available from URL: http://reenawadia.com/tricks-forremovable-partial-dentures/

27. Salman M, Saleem S. Effect of Different Denture Cleanser Solution on Some Mechanical and Physical Properties of Nylon and Acrylic Denture Base Material. J Bagh College Dentistry Vol.23; 2011.

28. Paranhos H, Orsi I, Zaniquelli O, Zuccolotto M, Magalhaes F. Effect of Chemical Denture Cleansers on Flexural Resistance and Color Changes of MicrowavePolymerized Acrylic Resins. J Oral Sci. July/September Vol 7; 2008: 1580-1581.

29. Dagar SR, Pakhan AJ, Thombare RU, et al. The evaluation of flexural strength and impact strength of heat polymerized polymethyl methacrylate denture base resin 
reinforced with glass and nylon fibers : An in vitro study. J Ind Pros Soc 2008, 8(2):98-105.

30. Chittaranjan B, Taruna. Material and Methods for Cleaning the Dentures. Indian Journal of Dental Advancements; 2010.

31. Chittaranjan B, Taruna, Sudhir, Bharath. Material and methods for cleaning the denture. Indian Journal of Dental Advancement; 2011:3(1) : 424.

32. Paranhos HDFO, Peracini A, Pisani MX, Oliveria VCD, Souza RFD, Lovato CHS. Color Stability, Surfaces Roughness and Flexural Strength of an Acrylic Resin Submitted to Simulated Overmight Immersion in Denture Cleansers. Brazil; Brazilian Dental Journal; 2013: 24(2):152-6.

33. Thomas D. Ingredients in denture cleanser. 2014. Available at: http://www.livestrong.com/article/121826-ingredients-denture-cleaners/.

34. Shangyuchen cherish world with oxygen chemistry. Sodium perborate monohydrate tetrahydrate. 2012. Available at: http://www.runyoutech.com/sodiumperboratmonohydrate- tetrahidrate.htm

35. Shangyuchen cherish world with oxygen chemistry. Potassium monopersulfate. 2012. Available from URL: http://www.runyyoutech.com/potassiummonopersulfate.htm

36. Polident. Perawatan Gigi Tiruan. [Cited: 10 Des 2016.] Available from URL: www.gsk-indonesia.com/0_repository/polident.pdf.

37. Sumono A, Wulan A. The Use of Bay Leaf (Eugenia Polyantha Wight) in Dentistry. Dental Journal; $2008: 148$.

38. Wijayakusuma. Tanaman Berkhasiat Obat di Indonesia. Jilid 2. Jakarta; Pustaka Kartini; 1995.

39. Siswandono. Soekardjo. Kimia Medisinal. Surabaya; Airlangga University Press; 2000.

40. Sumardjo D. Pengantar Kimia: Buku Panduan Kuliah Mahasiswa Kedokteran. Jakarta; EGC; 2009.

41. Sabir A. Pemanfaatan Flavonoid di Bidang Kedokteran Gigi. Majalah Kedokteran Gigi Edisi Khusus Temu Ilmiah Nasional III. Surbaya: FKG Unair; 2003: 81-87.

42. Rahardjo M.B. Kemampuan Alium sativum Linn dan Kaempferia galanga dalam Menghambat Pertumbuhan Streptococcus mutans. Majalah Kedokteran Gigi Edisi FORIL V. Surabaya: FKG Unair; 1996: 818-823.

43. Composite World. CAMX 2015 Preview: Shimadzu Scientific Instruments. [Cited: 10 Nov 2015.] Available from URL: https://www.compositesworld.com/products/camx-2015-_ preview-shimadzuscientific-instruments

44. Anusavice KJ. Philps: Buku ajar ilmu kedokteran gigi. Ahli bahasa: Budiman JA, Purwoko S. Jakarta: Penerbit Buku Kedokteran EGC; 2003. hal. 197-8

45. Pantow F, Siagian K, Pangemanan D. Perbedaan Kekuatan Transversal Basis Resin Akrilik Polimerisasi Panas pada Perendaman Minuman Beralkohol dan Aquades. Jurnal e-Gigi; 2015 : 399-2.

46. Dhena, S.E.M. Pengaruh Berbagai Konsentrasi Perasan Daun Salam (Eugenia polyantha Wight) sebagai Bahan Pembersih Gigi Tiruan terhadap Jumlah Candida albicans pada Lempeng Resin Akrilik. Tidak Diterbitkan. Skripsi.Jember: FKG UNEJ. 2006.

47. O'Brien, J.W. Dental Materials and Their Selection. $3^{\text {rd }}$ ed. Chicago: Quintessence. 2002. 